\title{
Aspects of Research Training and Commercialization Research Results
}

\author{
Evgeniy Bryndin \\ Research Center "Nature Informatics", Novosibirsk, Russia
}

Email address:

bryndin15@yandex.ru

To cite this article:

Evgeniy Bryndin. Aspects of Research Training and Commercialization Research Results. Science Journal of Education. Vol. 9, No. 1, 2021, pp. 6-13. doi: 10.11648/j.sjedu.20210901.12

Received: January 26, 2021; Accepted: February 6, 2021; Published: February 10, 2021

\begin{abstract}
The synergy of integration of science and education gives an accelerated educational effect in the training of highly qualified researchers. The accelerated process of training highly qualified researchers is implemented through the integration of higher education with advanced research fundamental science. Education and science, especially in their synergistic synthesis, are increasingly becoming the engine of technological progress, without which socio-economic progress is unthinkable in our time. High-quality training of researchers, based on an alliance with scientific activities, is a priority policy in all developed countries of the world, as well as a necessary component of the institutional structure of an innovative economy and business. The reproduction of highly qualified researchers who meet the requirements of an innovative economy and business has a high priority. Large corporations should invest sufficiently in research and development in the field of high technology, training specialists of appropriate quantity and quality, and form a system of public-private partnership in higher education. The creation of large educational complexes based on the joint activities of the university and the production sector is one of the most important areas of intersectoral cooperation for the development of high-tech industry. The commercialization of the transdisciplinary research process and its reproduction is difficult in the national framework due to the lack of the necessary modern technology and technology, skilled personnel, narrowness of the domestic market, and insufficient investment. Commercialization and reproduction of the transdisciplinary research process is possible only with intensive foreign economic relations and the reproduction of intellectual and research human capital.
\end{abstract}

Keywords: Intellectual Capital, Research Activities, International Cooperation

\section{Introduction}

In era of rapid technological development, universities must provide continuous learning, improve the learning ecosystem to train competent personnel with financial, legal, digital, entrepreneurial and professional literacy and systemic, interdisciplinary, innovative and strategic thinking. Transformational mobility of universities serves as a tool to increase the efficiency of university management, increase the quality of education and ensure its maximum individualization for the needs of a specific study and employer. The principle of learning mobility is implemented by filling and changing the educational process in accordance with the requests of the students themselves. The principle of learning mobility makes it possible to respond flexibly to changes in the needs of individual companies and subjects of the federation. This principle is manifested through the constant transformation of the functional and organizational structure, allowing universities to adapt to the training of personnel on rapidly changing technologies of the innovative industry and industry. The principle of mobility itself manifests itself in the variety of means, methods, organizational forms of the system of all levels of education, their flexibility and readiness for rapid transformation in accordance with the changing needs of the individual, the labor market, and society. It allows the use of various productive methodological systems and technologies, and consists in the creation of information networks, knowledge bases and data banks for distance education, as a result of which the student can adjust or supplement his educational program in the desired direction. To effectively ensure the principle of mobility, various information and communication technologies are used, which provide flexible and fast interaction between all participants in the 
educational process. Rapid technological development will lead to the replacement of the labor exchange with an exchange of competencies and the creation of an exchange of targeted education. The competence exchange will be formed by representatives of the technological sector of various enterprises of industry and services. The exchange of targeted education will be formed by universities together with the technological sector of industry and services. In the era of rapid technological development, universities should provide an individual trajectory of targeted competencies in terms of time, knowledge and skills of researcher, performer based on the technology sector, capitalization of knowledge and commercialization of research results.

\section{Formation of Research Activities}

Currently, Russia, China, the USA and the EU integration education have reached the optimal level of national research. Russia, China, the United States and the EU have the natural, financial and human resources necessary for research activities. The current political and economic situation of Russia prompted the country's leadership to implement a policy of self-reliance in research activities as strategic direction for ensuring political independence and national security.

Interdisciplinary research is based on the knowledge and skills of two or more different disciplines, which can range from the simple exchange of ideas to the mutual integration of concepts and methodologies to understand, justify and possibly manage the phenomena of super-complex systems. Interdisciplinary means collaboration in two or more scientific disciplines. The basic, initial form for an interdisciplinary form is multi-disciplinary, which involves sufficiently free interaction of scientists from different disciplines, which does not aim to formulate a common approach or obtain collective results. Interdisciplinary research aims to overcome the methodological and theoretical (including categorical) identities inherent in the scientific disciplines involved in interaction in order to create a new, common conceptual framework and obtain innovative results through it. It is with interdisciplinary research that the successes of modern natural sciences are associated. An interdisciplinary approach is best suited to explore complex, multilevel, heterogeneous, continuously changing institutional systems.

Transdisciplinary research aims to create a common system of axioms for a certain set of disciplines and integrate disciplinary paradigms for joint research and unity of knowledge. Transdisciplinary is understood as the study of the subject (more precisely, elements of the subject area) of one scientific discipline using the methods and terminology of another discipline; in other words, it is the study by representatives of one discipline of another subject.

It is necessary to develop transdiclinar research activities both through international cooperation and by improving its quality, and it is necessary to ensure a certain share of foreign participation necessary for the development of real competition. For research activities to become holistic, it is necessary, firstly, to increase the capitalization of fundamental knowledge, secondly, to work according to the model of self-sufficiency, thirdly, to conduct basic research also at the expense of the profits of applied science, fourthly, to attract young scientists in research activities for business. It is necessary through the exchange of competencies and targeted training to attract university students in research activities for industrial enterprises.

The development of priority areas of the state policy of the Russian Federation in the field of industry puts forward new requirements for the training of engineering personnel. It is necessary to develop intellectual capital in students at the university, forming its foundations and filling with professional content of intellectual capital. Intellectual capital as the dominant of intellectual and innovative foundations for the training of specialists is an integral part of the training of an engineer of the 21 st century.

Intelligent capital is used to increase the company's profit, attract new customers, create new products or otherwise improve business. This requires effective intellectual capital management. Effective intellectual capital management promotes innovation, Intelligent Capital Management can accelerate innovation, adapt it to more efficient development and use through organizational procedures and processes through which firms acquire, absorb, transform and use it to build dynamic organizational capacity.

Companies spend a lot of time and resources developing management experience and training their employees in specific areas of business in order to expand their intellectual abilities, employee trust, positive interpersonal relationships for the effective operation of the organization. The development of such qualities should be carried out within the framework of university education.

Education along individual educational trajectories on the basis of an educational management platform becomes relevant. The platform implements the main modules of the educational process, such as the designer of the educational space and educational modules, the selection of courses and the construction of the educational trajectory, individual schedule, academic performance and student ratings. Students learn the digital tools of the platform. The communication strategy includes representatives of all interested groups - from university professors to network platforms of other universities to carry out constant feedback with participants in the transformation. The student's planning unit at the university should be the educational communication in which he took part. Only those courses that were chosen by students fall into the load of teachers. The choice of the most popular courses is increasing. Students can choose courses from other universities presented on open online platforms. Help with the justification of trajectory selection accompanies the student throughout the entire learning process: the presence of specially designed self-determination points in the educational process, special modules in the educational process, tutor support. The multifactorial choice of individual 
educational trajectory includes specialties, courses, content, teachers, study groups, of and online educational communications and research aspects, modern knowledgebased technologies.

Modern knowledge-based technologies are presented in all spheres of activity and are aimed at the effective functioning of the national economy system. All this was reflected in the Program for the development of the coal industry of Russia for the period until 2030. At the same time, development requires the improvement of the system of training, professional retraining and advanced training of personnel for organizations with a focus on innovative and research qualities of specialists. The intellectual and research capital of modern specialists will contribute to increasing the capitalization of knowledge and commercialization of research activities [1].

Self-sufficiency of research activity is characterized by reproduction of demanded knowledge, commercialization of advanced technologies, development of artificial intelligence and modern technology oriented to the domestic and world market [2-7].

\section{Capitalization of Innovation Knowledge}

The innovation process is connected with changes in the field of knowledge presented in various areas of human life. At the same time, in the context of this process, a new knowledge is born, spread and turned into technology and profit. There was a close connection between mental activity, on the one hand, and material production, on the other. The pace and scale of translating knowledge into technology provides the basis for improvement. In the new economy, the firm's viable competitive advantages stem from its ability to use new knowledge.

Industries attract the profitable use of innovative professional knowledge for new technologies, services, organizational, technical and socio-economic solutions of a production, financial, commercial, administrative or other nature. The period of time from attracting innovative professional knowledge, creating innovation to its use is called the innovation lifecycle. Taking into account the sequence of work, the life cycle of innovation is considered as an innovative process. In the world economic literature, the innovation process is considered to be embodied in new products and technologies. In accordance with international standards, innovation is defined as the end result of innovation, embodied in a new or improved product introduced in the market, a new or improved technological process used in practice, or a new approach to social services.

Innovation makers are guided by criteria such as product lifecycle and cost-effectiveness. Their strategy aims to surpass competitors by creating an innovation that will be recognized as unique in a certain area. Scientific and technological developments and innovations act as an intermediate result of the scientific and production cycle and, as they are practically applied, turn into scientific and technological innovations - the end result. Scientific and technical developments and inventions are the application of new knowledge for the purpose of its practical application, and scientific and technical innovations are the materialization of new ideas and knowledge, discoveries, inventions and scientific and technical developments in the production process with the aim of their commercial implementation in order to satisfy certain needs of consumers. The indispensable properties of innovation are scientific and technological novelty and industrial applicability. If scientific and technological innovations meet market demand, then they bring profit to the industry. The identification of the actual status of profitability provides the basis for further innovative changes. A full analysis will not only identify possible areas of innovation, but also justify which of them is most cost-effective.

Modern companies are innovating as a means of increasing profits and gaining a wider market segment. Governments see them as a panacea for accelerating economic growth through increased competitiveness in the world. Innovation creates value and wealth by relying on some form of change (in any field - technology, materials, prices, services, demographics or even geopolitics), forming a new demand or resorting to new ways of replacing fixed capital and using "mature markets." Innovation promotes the movement of resources to higher productivity and profits.

Research has become the main authority around which most other factors of the modern business transformation of the knowledge economy revolve. The knowledge economy today stands on the verge of forming a new market segment the knowledge market. The knowledge market will be based on research and the capitalization of knowledge. The capitalization of innovation professional knowledge, profiting industries, is one of the main categories of the theory of human capital. This concept reflects a market assessment of the stock of human capital held by an individual. Thus, when capitalizing professional knowledge, it is necessary to first consider the main costs of human capital for their production.

The awareness of knowledge as a commodity and the most important resource for the development of civilization, the rapid development of the Internet, mobile communications and digital technologies that provide opportunities for the effective use of intellectual resources - all this determines fundamentally new approaches to the possibilities of the practical use of knowledge and the dynamics of changes taking place in society. Education at the university should be aimed primarily at teaching the student to solve practical problems, and not just at transferring knowledge. Russian universities are undergoing changes today that will lead to the emergence of a new type of university. Previously, universities were focused only on increasing knowledge, today the commercialization of developments becomes important. In third-generation universities, the development and commercialization of know-how and the capitalization of knowledge comes first. This raises issues such as intellectual 
property protection. We attract new knowledge, new skills. University 3.0 is primarily an open university that actively cooperates with industrial companies and foreign colleagues. Interaction with industry has a positive impact on the education process: students understand what disciplines they need for successful work, and in accordance with this, build their studies. Students should themselves be responsible for their education - to be able to choose those courses that they consider necessary. When students have access to different companies, they get an idea of what disciplines they need. They themselves are responsible for education. When responsibility is transferred to students, then this motivates them to develop. The goal of the university is to teach the student to solve problems, capitalize knowledge and implement it before commercialization.

\section{Digital Platform for Commercialization of Research Results}

The technology platform is an innovative ecosystem and acts as a provider of knowledge and technologies of the future, concentrating around itself a lot of companies, research centers, a variety of technical and logistics services, and, most importantly, consumers. The technology platform is used as a way of organizing the interaction of various participants (business structures, universities, state bodies, independent experts) to solve ultra-complex problems. Technological platforms are created in industries related to new knowledge (biomedicine, intelligent energy, nuclear industry, urban infrastructure, robotics, etc.). Universities in platforms often play the role of providers of scientific resources for research. In conditions of rapid changes and uncertainty, a new generation of managers, engineers, economists will have to solve not only qualitatively other tasks, but also act ahead of schedule, which requires special personnel competencies. The problem cannot be solved without a qualitative change in the content of educational products, training methods, and the prompt introduction of the results of scientific achievements into the educational process. There is a need for the formation of specialized university technology platforms focused on the commercialization of research activities. The technology platform does not do without the participation of universities, whose role increases sharply in solving poorly structured problems with a lack of necessary knowledge. Without cooperation with business, it is impossible to maintain high results in research activities, develop competencies, conduct a deep analysis of social and economic trends, improve educational content and focus on commercialization of research results.

The system of commercialization of research results, like the innovation system, is one of the types of open systems in which financial resources, material means in the form of products, patents, articles, as well as human resources function. It includes scientific organizations, universities, technology parks, business incubators, venture capital companies, enterprises and corporations. As well as structures providing regulatory, information and financial support.

To commercialize the results of scientific research, a digital platform of intelligent products is used. The digital platform of intelligent products is a constantly operating market platform on which, according to certain rules, transactions are made for the purchase and sale of intelligent products in the form of projects, developments of various degrees of readiness, laboratory and industrial samples and installations, patents, experimental productions, research results used in civilian industries. The digital platform of intelligent products also acts as an organizational regulator of innovative processes. Platforms are created for contacts between developers and investors, an information hub of interests of the business community, the state and the intellectual community. The results of research and development are displayed on the digital platform of intelligent products in the form of developments of various degrees of readiness, laboratory and industrial samples and installations, patents, experimental production, on the one hand. And creating technical and financial conditions for research and development - on the other hand (from the customer).

It is easier for representatives of business organizations to focus on addressing a development order in the presence of a market-based digital platform of intelligent products, in which a significant number of organizations of the country involved in research and development [8-15]. If business or industry manages to formulate task or order to create a technology, you can create a virtual team based on existing competencies that could implement this technology at the request of the industry. Conversely, when teams come together and offer innovative applied knowledge or technology to the industry.

For technology platform to perform the functions of communication and commercialization of results, it must be oriented towards a market competitive environment. A carefully designed marketing strategy for the technology platform is needed, including not only market research, the creation of breakthrough technologies, but also a thoughtful advertising campaign aimed at increasing the demand for innovation and increasing the prestige of scientific and engineering activities. In the context of globalization, the breakthrough technologies created by the technology platform must compete successfully with the technologies and products of the world's leading manufacturers. For successful commercialization, the result of research activities should be a complete product, demanded by both the Russian and world markets. For successful commercialization of the technology platform, as a communication platform, must be formed on the principles of marketing interaction.

The ethical interaction of the participants of the technological platform is carried out by an ensemble of intellectual agents based on standard case «Ethical application of ensemble intelligent agents». Ensembles of agents with artificial intelligence are multi-agent synergistic 
self-organizing systems that function according to the laws of development, synergy and self-organization. Intelligent agents use physical, informal and logical model of the environment. That is, they use both attributes and sets of entities, processes, relationships, etc.

Standard case, Application of ensemble of intelligent agents, defines parameters, characteristics, methods, human digital double models, knowledge, skills, behavior, images and other entities of intelligent virtual agent interaction. Intelligent virtual agent interaction uses categorical method of utility and preference.

The synergistic mechanisms of self-organization of technological ensembles of intelligent agents are basic for standardization in the application of ensembles in various fields.

Communicative-associative smart artificial intelligence with the help of an ensemble of diversified agents with smart interface help control ethical application of ensemble intelligent agents [14].

Cognitive robots and digital doubles through selfdeveloping ensembles of intelligent agents with synergistic interaction and creative communication artificial intelligence can master various high-tech professions and competencies. Their use in the industry increases labor productivity and economic efficiency of production. Their application in the social sphere improves the quality of life of a person and society. The widespread use of systems with creative communication artificial intelligence requires ethical standard so that their use does not cause harm. The development, implementation and use of an ethical standard for the use of cognitive robots and digital twins with creative communication artificial intelligence will increase the safety of their use through ethical communications. New concept of ethical communication is being introduced. Ethical communications are language, behavioural and operational relationships. Subjects of ethical communications are intellectual systems with linguistic, behavioral and active relationships. The objects of ethical communications are people. Ethical relationships between people and intellectual systems will be governed by an ethical standard.

Intellectual agents have professional images with language, behavioral and active communications, when each image is implemented by an agent with creative communication safe artificial intelligence. Language, behavioral and active communications of intellectual agents implement collective activities. The ethical standard through intelligent agents allows you to regulate the safe use of ensembles made of robots and digital doubles with creative communication artificial intelligence in the social sphere, industry and other professional fields. The use of systems with creative communication safe artificial intelligence requires responsibility from the developer and owner for harming others. If harm to others occurred due to the mistakes of the developer, then he bears responsibility and costs. If the damage to others occurred due to the fault of the owner due to non-compliance with the terms of use, then he bears responsibility and costs.

Ethical standard and legal regulation will help to become active members of society to systems with creative communication artificial intelligence. Standard case "Application of ensemble of intelligent agents" contributes to the formation of an ethical digital environment with smart artificial intelligence.

The standard case «Ethical application of ensemble intelligent agents» contains seven tables.

Table 1. General.

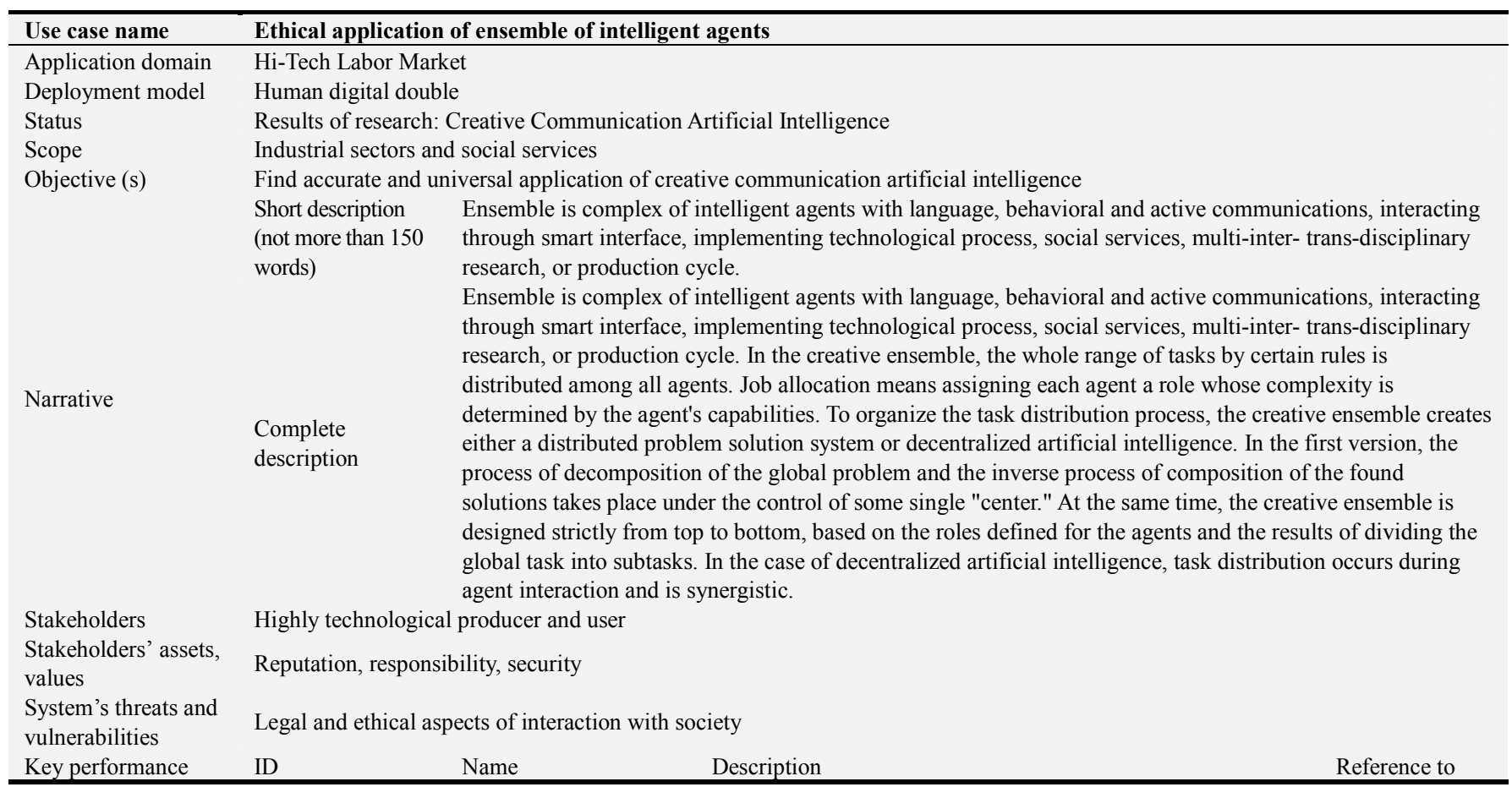




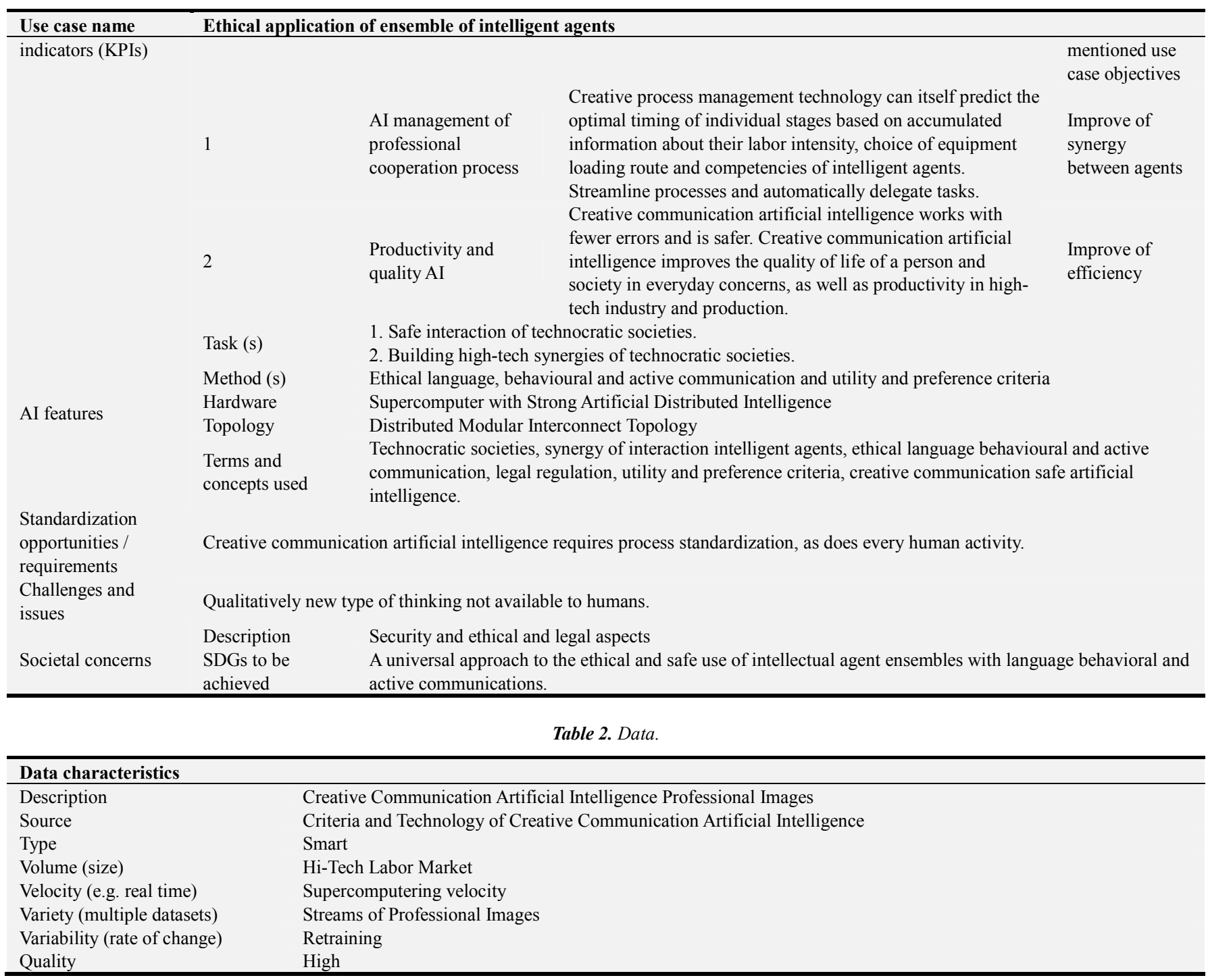

Table 3. Process scenario.

\begin{tabular}{|c|c|c|c|c|c|}
\hline \multicolumn{6}{|c|}{ Scenario conditions } \\
\hline N. & Scenario name & Scenario description & Triggering event & Pre-condition & Post-condition \\
\hline 1 & Training & $\begin{array}{l}\text { Training of intellectual agents in } \\
\text { professional images and language, } \\
\text { behavioral and active communications. }\end{array}$ & $\begin{array}{l}\text { By technological process of } \\
\text { modeling flow of professional } \\
\text { images and language, behavioral } \\
\text { and active communications }\end{array}$ & $\begin{array}{l}\text { Formatting of professional } \\
\text { images and language, } \\
\text { behavioral and active } \\
\text { communications }\end{array}$ & Management of safety \\
\hline 2 & Evaluation & Trained model & $\begin{array}{l}\text { Development of technological } \\
\text { thinking and behaviour }\end{array}$ & $\begin{array}{l}\text { Cognitive thinking patterns } \\
\text { and psychological behaviors }\end{array}$ & $\begin{array}{l}\text { Meeting KPI requirements } \\
\text { is condition of synergy }\end{array}$ \\
\hline 3 & Execution & Model and Technology Tooling & Interaction & Activization of Model & Completion of interaction \\
\hline 4 & Retraining & $\begin{array}{l}\text { Retrain model with training } \\
\text { professional images and language, } \\
\text { behavioral and active communications. }\end{array}$ & $\begin{array}{l}\text { New professional activities } \\
\text { and competencies }\end{array}$ & $\begin{array}{l}\text { Additional images and } \\
\text { communications }\end{array}$ & $\begin{array}{l}\text { Combining images and } \\
\text { communications }\end{array}$ \\
\hline
\end{tabular}

Table 4. Training.

\begin{tabular}{|c|c|c|c|c|c|}
\hline Scenario name & Training & & & & \\
\hline Step No. & Event & Name of process/Activity & Primary actor & Description of process/activity & Requirement \\
\hline 1 & $\begin{array}{l}\text { Sample professional images and } \\
\text { language, behavioral and active } \\
\text { communications is ready }\end{array}$ & $\begin{array}{l}\text { Specification and } \\
\text { classification }\end{array}$ & Manufacturer & $\begin{array}{l}\text { Transform sample professional } \\
\text { images and language, behavioral } \\
\text { and active communications }\end{array}$ & $\begin{array}{l}\text { Creative Communication } \\
\text { Artificial Intelligence } \\
\text { Software }\end{array}$ \\
\hline 2 & Completion of Step 1 & $\begin{array}{l}\text { Creating Experimental } \\
\text { professional images and } \\
\text { language, behavioral and } \\
\text { active communications }\end{array}$ & Manufacturer & $\begin{array}{l}\text { Development of language, } \\
\text { behavioral and active } \\
\text { communications through job } \\
\text { modelling }\end{array}$ & Software of modelling \\
\hline
\end{tabular}




\begin{tabular}{llllll}
\hline Scenario name & Training & & & \\
\hline Step No. & Event & Name of process/Activity & Primary actor & Description of process/activity & Requirement \\
\hline Completion of Step 2 & Model training & $\begin{array}{l}\text { AI solution } \\
\text { provider }\end{array}$ & $\begin{array}{l}\text { Model professional images and language, behavioral and active } \\
\text { lample professional } \\
\text { communications created by Step } \\
\text { images and language, } \\
\text { behavioral and active } \\
\text { communications }\end{array}$ \\
\hline
\end{tabular}

Table 5. Evaluation.

\begin{tabular}{llllll}
\hline Scenario name & Evaluation & & & & \\
\hline Step No. & Event & Name of process/Activity & Primary actor & Description of process/activity & Requirement \\
\hline 1 & $\begin{array}{l}\text { Completion of } \\
\text { training/retraining }\end{array}$ & Research & Manufacturer & $\begin{array}{l}\text { Model of sample experimental data } \\
\text { set created }\end{array}$ & $\begin{array}{l}\text { Ethical language, } \\
\text { behavioral and active } \\
\text { communications }\end{array}$ \\
2 & Completion of Step 1 & Identification & $\begin{array}{l}\text { AI solution } \\
\text { provider }\end{array}$ & $\begin{array}{l}\text { Based on new data, confirm that the } \\
\text { ensemble of intelligent agents performs } \\
\text { trained professional process. }\end{array}$ & Synergy \\
3 & Completion of Step 2 & $\begin{array}{l}\text { Evaluation } \\
\text { Input of evaluation } \\
\text { Output of evaluation }\end{array}$ & $\begin{array}{l}\text { Manufacturer } \\
\text { Comparison of Step 1 and Step 2 }\end{array}$ & Synergy \\
\hline
\end{tabular}

Table 6. Execution.

\begin{tabular}{llllll}
\hline Scenario name & Execution & & & & \\
\hline Step No. & Event & Name of process/Activity & Primary actor & Description of process/activity & Requirement \\
\hline 1 & $\begin{array}{l}\text { Analysis of } \\
\text { modeling results }\end{array}$ & Research & Manufacturer & $\begin{array}{l}\text { Development of set of experimental data through job } \\
\text { modelling }\end{array}$ & $\begin{array}{l}\text { Compatibility } \\
\text { Based on the modification of communications of } \\
\text { professional images according to the created } \\
\text { experimental set. }\end{array}$ \\
2 & $\begin{array}{l}\text { Completion of } \\
\text { Step 1 and Step 2 }\end{array}$ & $\begin{array}{l}\text { AI solution } \\
\text { provider }\end{array}$ & $\begin{array}{l}\text { Synergy } \\
\text { Input of Execution } \\
\text { Output of Execution }\end{array}$ & Sodification of communications of professional images & \\
\hline
\end{tabular}

Table 7. Retraining.

\begin{tabular}{|c|c|c|c|c|c|}
\hline Scenario name & Retraining & & & & \\
\hline Step No. & Event & Name of process /Activity & Primary actor & Description of process/activity & Requirement \\
\hline 1 & $\begin{array}{l}\text { New professional } \\
\text { activities and } \\
\text { competencies }\end{array}$ & Research & Manufacturer & $\begin{array}{l}\text { Additional professional images } \\
\text { and language, behavioral and } \\
\text { active communications }\end{array}$ & Completeness \\
\hline 2 & Completion of Step 1 & $\begin{array}{l}\text { Experimental data set } \\
\text { creation }\end{array}$ & Manufacturer & $\begin{array}{l}\text { Combining professional images } \\
\text { and language, behavioral and } \\
\text { active communications }\end{array}$ & Compatibility \\
\hline & Completion of Step 2 & Model training & AI solution provider & Comparison of phase 2 results & Synergy and quality \\
\hline \multicolumn{2}{|c|}{ Specification of retraining data } & \multicolumn{4}{|c|}{ Data of new professional activities and competencies } \\
\hline
\end{tabular}

\section{Conclusion}

Authorities, businesses and educational institutions will have to change to align with the needs of society, which is formed on an automated industrial basis. Mobility of governance must ensure economic growth; support high-tech competitive highvalue-added enterprises in the foreign market; support universities that train highly qualified professionals in demand in the labor market, especially IT specialists in the digital economy; develop production processes based on soft skills and world skills. The international experience of Japan, Singapore, China, South Korea, Germany, England, America shows that digital platforms for commercializing the research activities of an innovative high-tech economy improve the management and competitive ability of high-tech companies, as well as the training of highly qualified specialists with intellectual and research capital universities.

Commercialization is, first of all, the construction of a business based on the results of scientific research, in which technology authors, owners, investors participate. For scientists, technology transfer can also serve as a tool for finding and attracting additional funds to continue their scientific research. For investors - a tool to create a sustainable financial flow generating business. Commercialization of technologies (research and development) is any activity that is aimed at creating income from the use of the results of scientific research, scientific competencies.

Commercialization based on technology platforms in developed countries serves as a foundation for global competitiveness, which highlights the need for significant efforts to support and develop the production of knowledge, high technology and innovation in various fields of activity. The creation and promotion of a commercial offer is based on activities on marketing research, business planning and advertising and information support. In Europe and the USA, most of the marketing research is carried out by third-party organizations in collaboration with commercialization 
departments, while the division itself focuses more on business planning and advertising and information support on promoting a commercial offer, as an activity that is directly related to receiving a response from the market, involving parties interested in commercializing development. The commercialization of knowledge and technology is driving the creation of new and modernized industries.

Universities in Germany, most of which are combined into platform clusters and are focused on the issue of "Industry 4.0 ," based on digital production.

\section{References}

[1] Evgeniy Bryndin. Mission of universities in era of rapid technological development. Journal of Educational System Volume 4, Issue 1, 2020, PP 36-40.

[2] Evgeniy Bryndin. Diversified Transformation of University Inside and in Interaction with Industrial and Social Environment. Education Journal. Vol. 9, Issue 4, 2020. Pages: 95-98.

[3] Masloboev A. V., Langhans M. A multi-agent system for management information support of regional innovations. Scientific and Technical Journal of Information Technologies, Mechanics and Optics, 2018, vol. 18, no. 4, pp. 630-638.

[4] Wu Jun. Research on the Framework of Smart City Operating System Based on New ICTs. American Journal of Artificial Intelligence. Volume 4, Issue 1, June 2020, Pages: 36-41.

[5] CRONEMBERGER F, GIL-GARCIA J R. Big data and analytics as strategies to generate public value in smart cities: proposing an integrative framework $[\mathrm{M}]$. Switzerland: Springer Nature, 2019.

[6] Makridakis, S. The Forthcoming Artificial Intelligence (AI) Revolution: It is Impact on Society and Firms. Futures, 2017, 46-60.
[7] Webster, C., \& Ivanov, S. Robotics, artificial intelligence, and the evolving nature of work. Chapter 8 in book: Digital Transformation in Business and Society Theory and Cases (pp. 127-143). Publisher: Palgrave Macmillan. 2019.

[8] Evgeniy Bryndin. Directions of Development of Industry 4.0, Digital Technology and Social Economy. American Journal of Information Science and Technology. Volume 2, Issue 1. 2018. P. 9-17.

[9] A. X. Zhu, C. Z. Qin, P. Liang, F. Du. DIGITAL SOIL MAPPING FOR SMART AGRICULTURE: THE SOLIM METHOD AND SOFTWARE PLATFORMS. RUDN Journal of Agronomy and Animal Industries 2018 Vol. 13 No. 4.

[10] Hamid El Bilali, Francesco Bottalico, Giovanni Ottomano Palmisano, Roberto Capone. Information and Communication Technologies for Smart and Sustainable Agriculture. In book: 30th Scientific-Experts Conference of Agriculture and Food Industry (pp. 321-334). Publisher: Springer. 2020.

[11] Evgeniy Bryndin. Creation of Social Self-sufficient Digital Ecological Economy of Natural Needs of Healthy Living Activities. Resources and Environmental Economics, Vol. 2, Issue 2. 2020. pp. 184-190

[12] Jennifer Clapp. Precision Technologies for Agriculture: Digital Farming, Gene-Edited Crops, and the Politics of Sustainability. Global Environmental Politics 20: 3, August 2020.

[13] Evgeniy Bryndin. Formation and Management of Industry 5.0 by Systems with Artificial Intelligence and Technological Singularity. American Journal of Mechanical and Industrial Engineering. Volume 5, Issue 2. 2020. pp. 24-30.

[14] Evgeny Bryndin. Formation of International Ethical Digital Environment with Smart Artificial Intelligence. Automation, Control and Intelligent Systems. Volume 9, Issue 1, 2021. pp. 27-38.

[15] Andrew Little. Four Companies at the Center of the Telemedicine \& Digital Health Revolution. EDOC-Global X Telemedicine \& Digital Health ETF, Dec 10, 2020. 